\title{
PERFORMANCE ANALYSIS OF OPTIMIZATION METHODS FOR SOLVING TRAVELING SALESMAN PROBLEM
}

The subject of this research is distance and time of several city tour problems which known as traveling salesman problem (tsp). The goal is to find out the gaps of distance and time between two types of optimization methods in traveling salesman problem: exact and approximate. Exact method yields optimal solution but spends more time when the number of cities is increasing and approximate method yields near optimal solution even optimal but spends less time than exact methods. The task in this study is to identify and formulate each algorithm for each method, then to run each algorithm with the same input and to get the research output: total distance, and the last to compare both methods: advantage and limitation. Methods used are Brute Force (BF) and Branch and Bound (B\&B) algorithms which are categorized as exact methods are compared with Artificial Bee Colony (ABC), Tabu Search (TS) and Simulated Annealing (SA) algorithms which are categorized as approximate methods or known as a heuristics method. These three approximate methods are chosen because they are effective algorithms, easy to implement and provide good solutions for combinatorial optimization problems. Exact and approximate algorithms are tested in several sizes of city tour problems: 6, 9, 10, 16, 17, 25, 42, and 58 cities. 17, 42 and 58 cities are derived from tsplib: a library of sample instances for tsp; and others are taken from big cities in Java (West, Central, East) island. All of the algorithms are run by MATLAB program. The results show that exact method is better in time performance for problem size less than 25 cities and both exact and approximate methods yield optimal solution. For problem sizes that have more than 25 cities, approximate method - Artificial Bee Colony (ABC) yields better time which is approximately $37 \%$ less than exact and deviates $0.0197 \%$ for distance from exact method. The conclusion is to apply exact method for problem size that is less than 25 cities and approximate method for problem size that is more than 25 cities. The gap of time will be increasing between two methods when sample size becomes larger.

Keywords: traveling salesman problem; optimization method; exact method; approximate methods; gaps.

\section{Introduction}

Traveling salesman problem, called TSP is a description of a large class of problems known as combinatorial optimization problems and literally also known as a Chinese postman problem or single vehicle routing problem (VRP). Many real-world problems can be modeled as variants of TSP as a real-world problems are often more complicated than TSP. Since there are many powerful tranformation technique to convert the variants to TSP, any outcome for TSP can be used for a wide variety of real-world of problems [1,2]. TSP is one of the most important transportation problems in operational logistics. Transporation is needed to guarantee the mobility of people and goods and as part of the economic system, transportation has an important function in national development [3]. The concept of TSP is described as follows: a salesman or a vehicle has a number of cities to visit with a distance of time between two cities and each city is visited only once (Hamiltonian cycle) and returns to the starting city then the total distance or time is minimized $[4,5,6]$. Distance is a key factor in transportation. According to $[7,8]$ the distance controls for transportation cost, and for health center, distance plays a crucial role in health service accessibility [9], for food distribution, distance should be considered when assessing the environmental impact of transporting food [10]. Transportation cost is about one third or two third of total logistics cost [11]. The facts tell us about the need to search the shortest route in order to minimize cost, minimize risk and minimize damage.

There are two types of optimization methods: one is exact method and the other one is approximate method [12]. Exact methods produce optimal solutions and approximate (heuristics) methods produce high solutions in a reasonable time but no guarantee optimal solution. Brute force, Branch and Bound, Dynamic Programming are examples of exact methods or limited search methods [13] where Artificial Bee Colony, Tabu Search and Simulated Annealing are examples of approximate methods. Although approximate method does not produce optimal solution but it has some advantages such as short searching time of solution compared to exact methods, near optimal solution even optimal, and simplicity of implementation.

Brute Force algorithm searches all solution space, exhaustive search for combinatorial problem, generates a list of all potential solutions to the problem in a systematic manner and evaluates potential solutions one by one, disqualifies infeasible ones and keeps track of the best one found for an optimization problem [14].

Branch and Bound (B\&B) algorithm is a fundamental and widely used methodology for producing exact solutions to NP-hard optimization problems. This method is proposed by Land \& Doig. B\&B algorithm creates and prunes the nodes and this happens in a recursive way. This strategy has three main components: branching, bounding, and the selection of the next node. Important decisions have to be made that influence the performance of the algorithm [15] this solves a discrete optimization problem by breaking up its feasible set into smaller subsets, calculating bounds on the objective function value over each subset and using them to discard certain subsets from further consideration. The bounds are obtained by replacing the problem over a given subset with an easier problem, such that the solution value of the latter bounds that of the former. The procedure ends when each subset has either produced a feasible solution or contains no better solution than the one already in hand. The best solution found is a global optimum [16]. 
Artificial Bee Colony (ABC) algorithm is a heuristic method and optimization algorithm that comes under Swarm Intelligence and inspired by social behavior of natural bees. This method introduced by Dervis Karaboga in 2005. The term swarm is used in a general manner to refer to any restrained collection of interacting agents or individuals. This ABC algorithm has been compared with that of differential evolution (DE), particle swarm optimization (PSO) and evolutionary algorithm (EA), and the result shows the ABC perform better than DE, PSO and EA [17]. Bee colony optimization has beeen successfully applied to various hard combinatorial optimization problems, mostly in transportation, location and scheduling fields [18].

Tabu Search (TS) algorithm is a powerful algorithm approach that has been implemented with great success to any difficult combinatorial problems and generally provide good solutions very early in the search. TS was proposed by Fred Glover in 1986 which allow Local Search (LS) to overcome local optima. The basic principle of TS is to pursue LS when finds a local optimum by allowing non improving movement and back to previous visited is prevented by the use of memories which called tabu lists [19].

Simulated Annealing (SA) algorithm is a heuristic algorithm for obtaining good solutions and has several interesting features such as easy to implement, can be generally used to a wide range problems and can provide high quality solutions to many problems [20]. SA is regarded as one of most commons heuristics technique [21].

Based on the paper published above, both exact and approximate methods have outstanding performance where exact method yields optimal solution but time consuming, and on the other hand, approximate yields near optimal solution but faster than exact method. From this point of view, performance analysis needs to be conducted to get the percentage of difference both solution and processing time, so the goal in this paper is to find how large the differences are for solution and time between exact and approximate methods based on case study of goods distribution to varied number of destinations in cities - small and medium size.

\section{Materials and methods}

1. Brute Force (BF) algorithm is a straightforward approach and usually based on problem statement and definitions of concepts involved. This solution to combinatorial problems, this suggests generating each and every combinatorial object such as permutations, combinations or subsets of a set of the problem, selecting those of them that satisfying all the constraints, and then finding a desired object [22].

\%Input: a list $P$ of $n(n \geq 2)$ points $P_{1}=\left(x_{1}, y_{1}\right), \ldots$, $P_{n}=\left(x_{n}, y_{n}\right)$
\%Output: Indices index 1 and index 2 of the closet pair of points

Dmin $\leftarrow \infty$

for $i \leftarrow 1$ to $n-1$ do

for $j \leftarrow i+1$ to $n$ do

$d \leftarrow \operatorname{sqrt}\left(\left(x_{i}-x_{j}\right) 2+\left(y_{i}-y_{j}\right) 2\right) / / \operatorname{sqrt}$ is

the squre root function

if $d<d \mathrm{~min}$

$d$ min $\leftarrow d$; index $1 \leftarrow i$; index $2 \leftarrow j$

return index 1 , index 2

\section{Branch and Bound $(B \& B)$ algorithm}

The branch and bound (B\&B) algorithm implicitly enumerates all possible solutions to the problem under consideration, by storing partial solutions which called subproblems in the structure of tree. Unexplored nodes generate children by partitioning the solution space into smaller regions that can be solved recursively (branching) and rules are used to prune off regions of the search space that provably suboptimal (bounding). When all trees has been explored, the best solution found in the search and is returned [23]. The pseudocode is:

Set $L=\{X\}$ and initialize $\hat{x}$

while $L \neq \varphi$ :

Select a subproblem $\mathrm{S}$ from $\mathrm{L}$ to explore

If a solution $\hat{x}^{\prime} \in\{x \in S \mid f(x)<f(\hat{x})\}$ can

be found : Set $\hat{x}=\hat{x}^{\prime}$

If $S$ can not be pruned:

Partition $S$ into $S_{1}, S_{2}, \ldots, S_{r}$

Insert $S_{1}, S_{2}, \ldots, S_{r}$ into $L$

Remove $S$ from $L$

Return $\hat{x}$

\section{Artificial Bee Colony (ABC) algorithm}

$\mathrm{ABC}$ algorithm is simple, easy, very fast and it can be effectively applied to combinatorial optimization problem, in this algorithm, the bees are divided in three groups: employed bees, onlooker bees and scout bees. Each food source position represents a candidate solution of optimization problem. The number of employed bees or the onlooker bees is equal to the number of solutions in the population.

This below equation represents an initial solution which random route between 1 and 25 generated by this equation. At the same time, a scout bee searches the new foods when a source is abandoned [24, 25]:

$$
x_{i j}=x_{j}^{\min }+\operatorname{rand}(0,1)\left(x_{j}^{\max }-x_{j}^{\min }\right),
$$

where abandoned source is $x_{i}$ and $j \in\{1,2, \ldots D\} ; D$ is the number of optimization parameters

This following equation represents the employed bee phase that performs random modifications on adjacent to a solution.

$$
v_{i j}=x_{i j}+\phi_{i j}\left(x_{i j}-x_{k j}\right),
$$


where: $k \in\{1,2, \ldots, S N\}$ and $\{1,2, \ldots D\}$ are randomly chosen indexes, but $\mathrm{k}$ has to be different from $i ; \phi_{i, j}$ is a random number between -1 and $1 ; x_{i, j}$ is a comparison of two food positions; $\mathrm{SN}$ is the number of food sources.

The number of food sources is equal to the number of employed bees

Then, the last equation, onlooker bee choose a food source with probability proportional to the quality of food source

$$
\text { fitness }_{i}=\left\{\begin{array}{lll}
\frac{1}{1+f_{i}} & \text { if } & f_{i} \geq 0 \\
1+a b s\left(f_{i}\right) & \text { if } & f_{i} \geq 0
\end{array}\right\},
$$

where $f_{i}$ is the fitness value of the solution $\mathrm{i}$

In this study, number of cities is $6,9,10,16,17,25$, 42,58 and the manipulating operators are swap, insertion, and reversion.

A short algorithm is shown below [26]:

Initialize population.

\section{Repeat}

Place the employed bees on their food sources and determine their nectar amounts

Calculate the probability value of the sources with which they are preferred by the onlooker bees

Place the onlooker bees on the food sources depending on their nectar amounts

Stop the exploitation process of the sources exhausted by the bees

Send the scouts to the search area for discovering new food sources randomly

Memorize the best food source found so far

Until requirements are met

\section{Tabu Search (TS) algorithm}

The main idea of this algorithm is allowing climbing moves when there is no improving neighbouring solution exists such as a move is allowed even if a new solution s' from neighbourhood of the current solution $\mathrm{s}$ is worse than the current one. In nature, return to the locally optimal solutions previously visited is not allowed in order to avoid cycling of the search. TS is based on a methodology of prohibitions: some moves are frozen (tabu) from time to time. The pseudocode for the standard (pure) tabu search as follows [27]:

Function tabu_search(s);

// input: $s$ - the initial solution; output: $s^{*}-$ the best solution found //

$$
s^{*}:=s
$$

initialize the tabu list $T$;

repeat // continue the main cycle of TS //

given neighbourhood function $\theta$, tabu list $T$, and aspiration criterion,

find the best possible solution $s$ ' $\in \theta^{\prime}(s) \subseteq \theta(s)$, where $\theta^{\prime}(s)$ consists of solutions that (or their "attributes") are not currently in the tabu list $T$ or satisfy the aspiration criterion;

$s:=s^{\prime} ; / /$ replace the current solution by new one //

insert the solution $s$ (or its "attribute") into the tabu list $T$;

if $f(\mathrm{~s})<f\left(\mathrm{~s}^{*}\right)$ then $s^{*}:=s ; / /$ save the best so far solution //

update the tabu list $T$

until termination criterion is satisfied;

return $s^{*}$

end

\section{Simulated Annealing (SA) algorithm}

Is very usefull in finding global optima in the presence of local optima large numbers. The simulated annealing algorithm starts from a higher temperature which is called the initial temperature. When the temperature decreases gradually, the solution tends to be stable but the solution may be a local optimal solution. Pseudocode is as follows [28]:

Input: initial temperature $T 0$, minimum temperature Tmin, maximum number of iteration $K \max$, probablity of temperature drop $\rho$;

Output: the optimal solution $X_{\text {best }}$

Generating an initial solution $X_{0}$;

$X_{\text {best }} \leftarrow X_{0}$;

Computing the value of objective function $f\left(X_{0}\right)$ and $f\left(X_{\text {best }}\right)$

$T_{i} \leftarrow T_{0}$;

While $T_{i}>T_{\min }$ do

$\Delta \mathrm{f} \leftarrow f\left(X_{\text {new }}\right)-f\left(X_{\text {best }}\right)$;

If $\Delta f<0$ then $X_{\text {best }} \leftarrow X_{\text {new }}$;

Endif

If $\Delta f \geq 0$ then $\rho \leftarrow e^{\frac{\Delta f}{T}}$;

If $c \leftarrow$ random $[0,1] \geq \rho$ then $X_{\text {best }} \leftarrow X_{\text {new }}$;

Else $X_{\text {best }} \leftarrow X_{\text {best }}$;

End if

End if

$i \leftarrow i+1 ; T_{i} \leftarrow \rho \times T_{i} ;$

end while

Return Xbest;

\section{Research Methodology}

Doing this research, there are some steps that must be followed, starting from goal setting, analysing and drawing the conclusion which can be seen in fig. 1.

\section{Results and Discussions}

\section{Results}

By using MATLAB program based PC, the results for every algorithm indicated in table 1. 


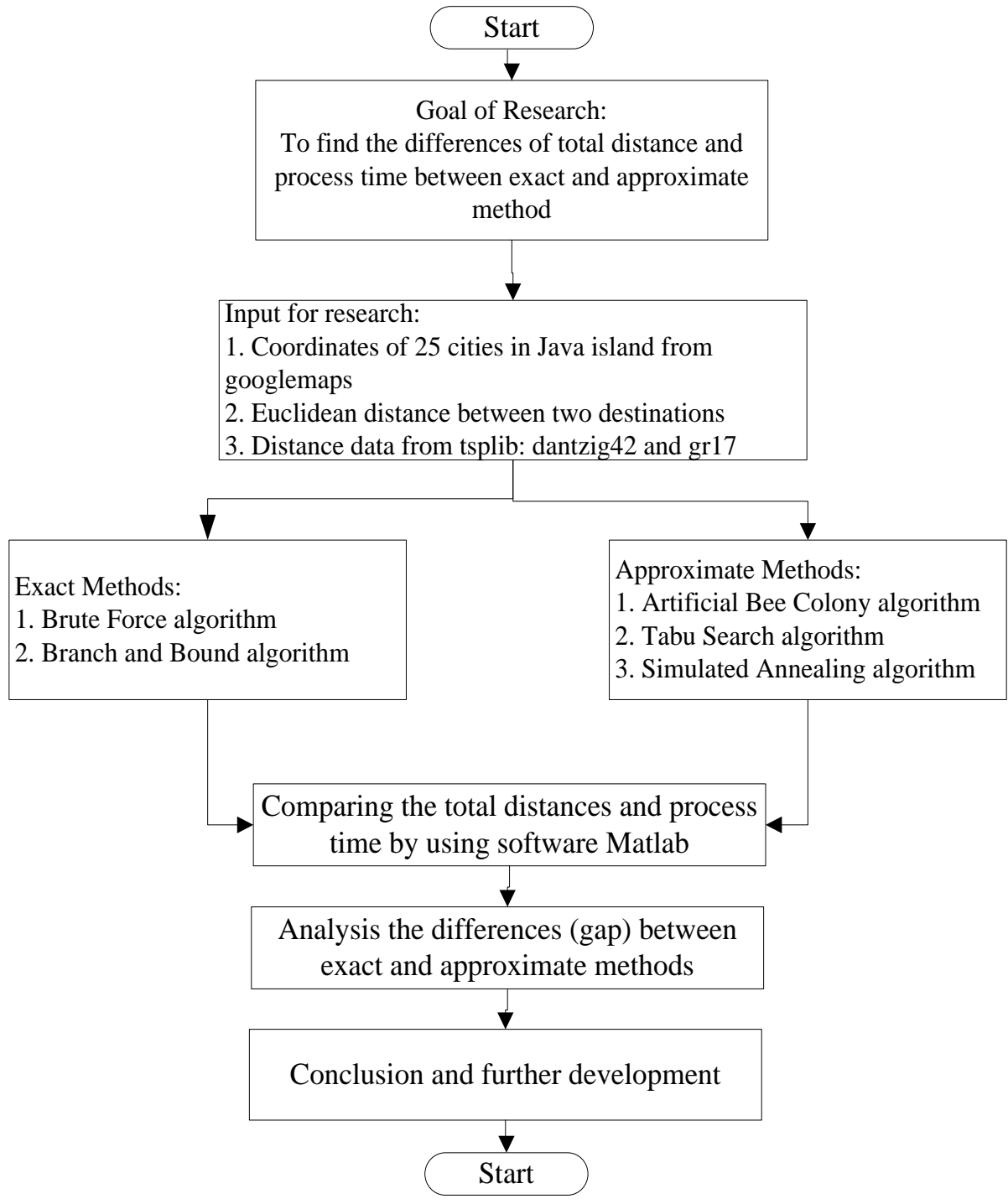

Fig. 1. Research Methodology

Tabel 1. Comparison of distance and time

\begin{tabular}{|c|c|c|c|c|c|c|c|c|c|c|c|c|c|c|c|c|}
\hline & \multicolumn{2}{|c|}{6 cities } & \multicolumn{2}{|c|}{9 cities } & \multicolumn{2}{|c|}{$\mathbf{1 0}$ cities } & \multicolumn{2}{c|}{$\mathbf{1 6}$ cities } & \multicolumn{2}{c|}{$\begin{array}{c}\text { Gr17 } \\
\text { (tsplib) }\end{array}$} & \multicolumn{2}{|c|}{$\mathbf{2 5}$ cities } & \multicolumn{2}{c|}{$\begin{array}{c}\text { Dantzig42 } \\
\text { (tsplib) }\end{array}$} & Brazil58 (tsplib) \\
\hline Algo & Dist & Time & Dist & Time & Dist & Time & Dist & Time & Dist & Time & Dist & Time & Dist & Time & Dist & Time \\
\hline BF* & 587 & 2 & 608 & 18 & 861 & 111 & - & - & - & - & - & - & - & - & - & - \\
\hline B\&B & 587 & 0.14 & 608 & 0.06 & 861 & 0.31 & 1,465 & 4.69 & 2,085 & 3.87 & 2,251 & 12,750 & 699 & 187 & 25,395 & $>82,800$ \\
\hline BKS & & & & & & & & & 2,085 & & 2,251 & & 699 & & 25,395 & \\
\hline ABC & 587 & 5 & 608 & 5 & 861 & 6 & 1,465 & 7 & 2,085 & 6 & 2,251 & 6 & 699 & 117 & 25,400 & 740 \\
\hline TS & 587 & 5 & 608 & 6 & 861 & 7 & 1,636 & 11 & 2,085 & 12 & 2,556 & 22 & 856 & 51 & & \\
\hline SA & 587 & 34 & 608 & 23 & 861 & 26 & 1,465 & 33 & 2,085 & 30 & 2,274 & 29 & 774 & 29 & & \\
\hline
\end{tabular}

*the time cost is too expensive; Dist means distance; $B K S=$ Best Known Solution

In this study, the first thing to see is the results of distance for each algorithm. In the case of 6 cities to 10 cities, all algorithms yield the same distances and competitive process time. Starting from study of 16 cities, TS does not yield optimal solution where SA starts from the case of 25 cities. BF algorithm is less efficient tool when the cities grow to more than 10 cities, because it will grow like $n$ !, so if there is 11 cities, then time needed will be 11 times as long as the time for 10 cities. When the number of cities is increasing to more than twenty cities, one can benefit from approximate method becaue it has less time than exact method and the result is also optimal. $\mathrm{ABC}$ algorithm is more powerful than others and from time aspect, $\mathrm{ABC}$ has less time about $37.43 \%$ than $\mathrm{B} \& \mathrm{~B}$ algorithm for case Dantzig42 shown in fig. 2. ABC algorithm also tested for tsplib brazil58 shown in figure 3, the distance deviates only $0.0197 \%$ but amount of time is increasing compared to Dantzig42. For case of cities is less than or the same as 10 cities, both exact and approximate methods show the same distance, the gap is only in time. 


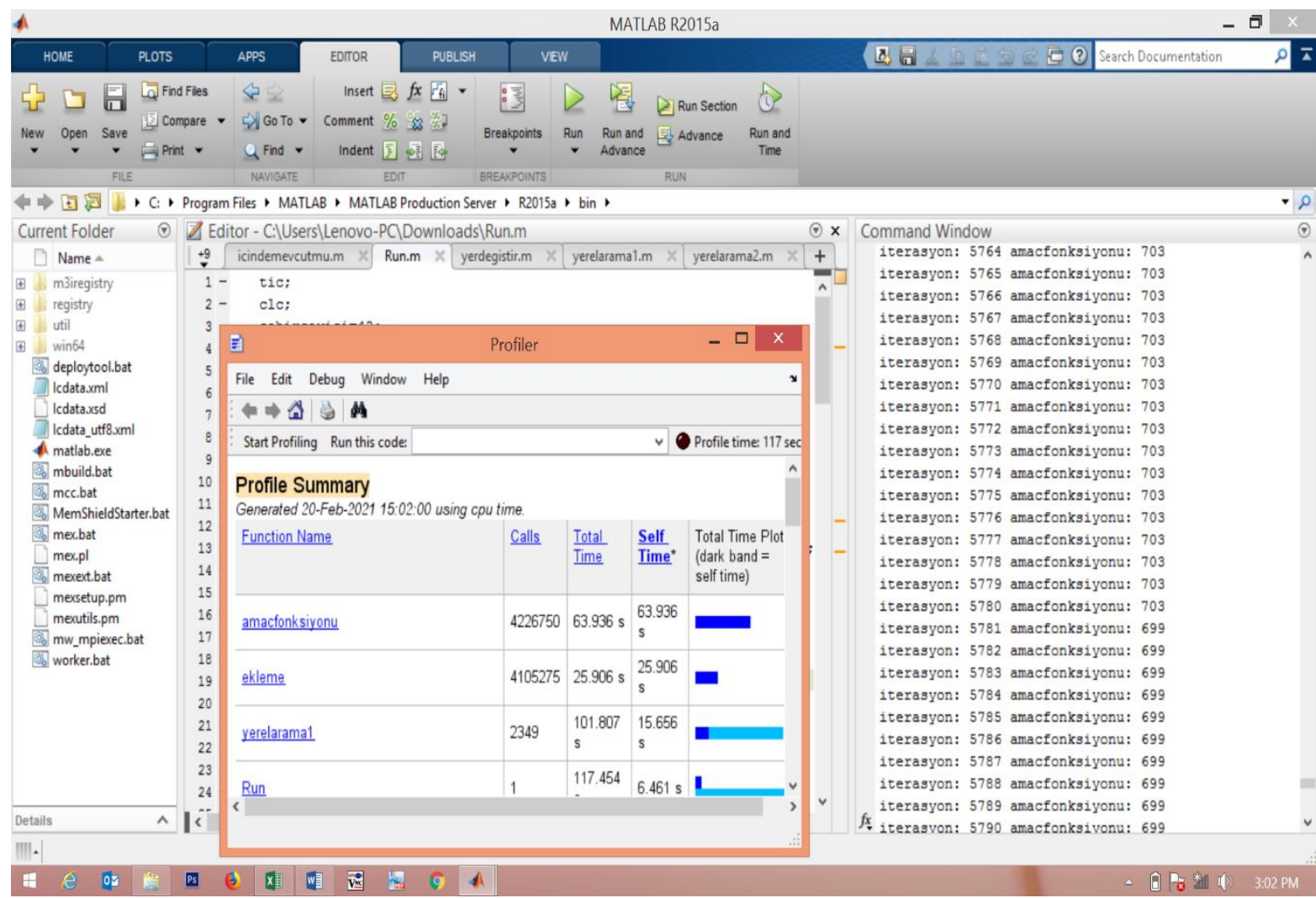

Fig. 2. ABC algorithm tested on dantzig42 tsplib

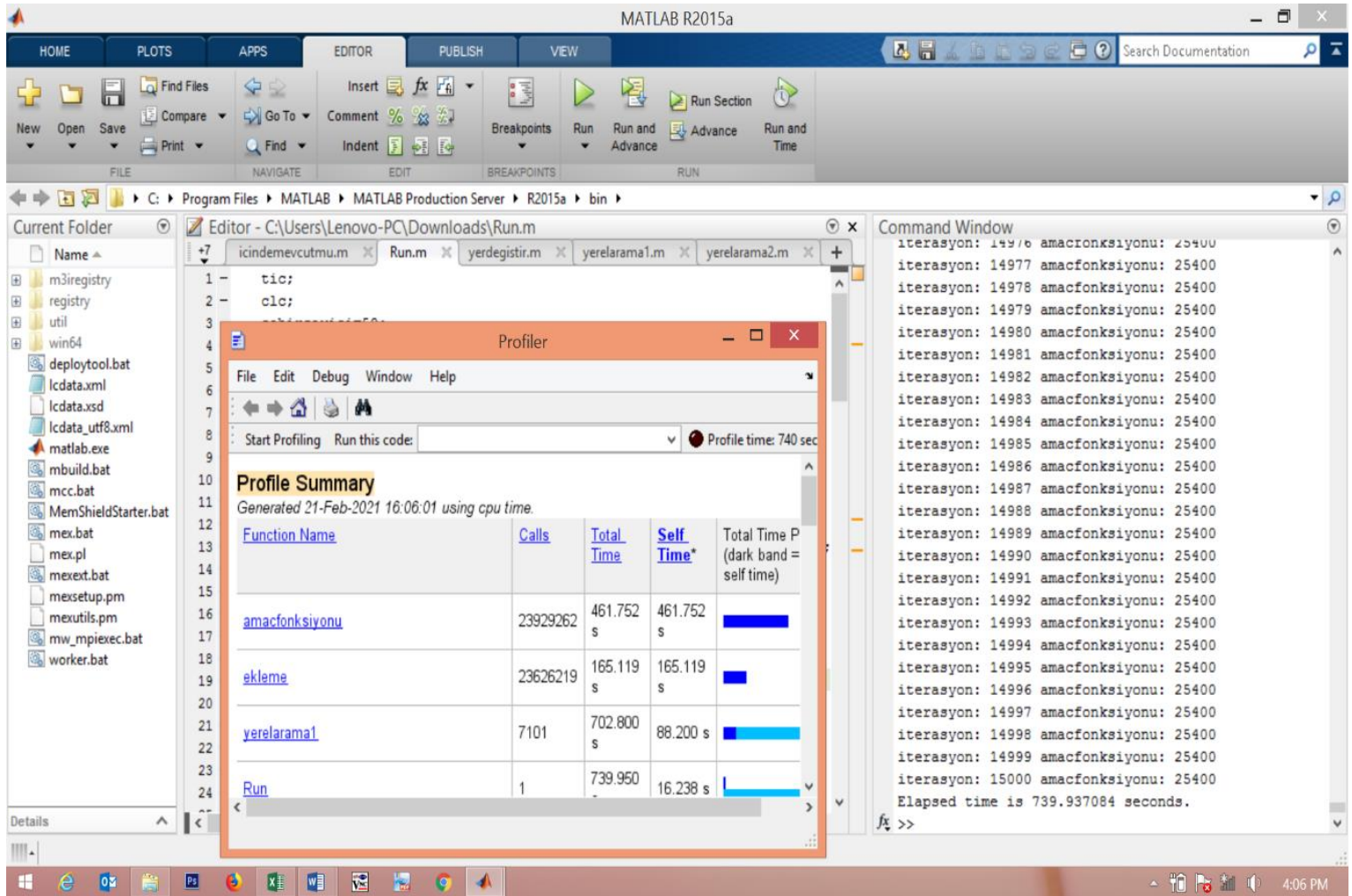

Fig. 3. ABC algorithm tested on brazil58 tsplib

\section{Discussions}

There are numerous algorithms and cases now, then each algorithm in this manuscript must be tested on larger size, validated and compared with other algorithms especially approximate methods and cases from other countries in order to increase conviction for users both for distance and time. According to [29], B\&B algorithm is suitable for solving less than 60 locations, then one should consider to apply approximate method. 


\section{Conclusions and Further Development}

Transportation distance can be minimized by choosing the shortest route. There are two optimization methods, one is exact and the other is approximate. Exact methods - Brute Force and Branch and Bound algorithms provides optimal solution but Brute Force algorithm yields about $n$ ! when the number of cities is more than 10 , and Branch and Bound algorithm is less efficient in time when the number of cities is more than 25 cities than approximate method - Artificial Bee Colony algorithm. Exact method is fit to problems less than 25 cities and Approximate method is fit to problems larger than 25 cities.

\section{References}

1. Dimitrijevic, V., Saric, Z. (1997), "An Efficient Transformation of The Generalized Traveling Salesman Problem into The Traveling Salesman Problem on Diagraphs", Information Sciences, Vol. 102, Issues 1-4, P. 105-110. DOI: https://doi.org/10.1016/S00200255(96)00084-9

2. Baniasadi, P., Foumani, M., Miles, K. S., Ejov, V. (2020), "A Transformation Technique for The Clustered Generalized Traveling Salesman Problem with Applications to Logistics", European Journal of Operational Research, Vol. 285, Issue 2, P. 444-457. DOI: https://doi.org/10.1016/j.ejor

3. BPS - Statistik Indonesia (2019), "Land Transportation Statistics, Statistik Transportasi Darat", available at : www.bps.go.id

4. Saud, S., Kodaz, H., Babaoglu, I. (2017), "Solving the Traveling Salesman Problem Using Optimization Algorithms", IAIT Conference Proceddings. The 9th International Conference on Advances in Information Technology, Vol. 2017. DOI: https://doi.org/10.18502/kss.v3i1.1394

5. Jadczak, R. (2014), "Traveling Salesman Problem: Approach to Optimality", De Gruyter Open, Vol. XV, Issue 2, P. 157-159. DOI: https://doi.org/10.2478/eam-2014-0024

6. Chandra, A., Setiawan, B. (2018), "Optimizing the Distribution Routes Using Vehicle Routing Problem (VRP) Method", Journal Manajemen Transportasi dan Logistik, Vol. 05, No. 2, available at : http://ejournal.stmt-trisakti.ac.id/index.php/jmtranslog

7. Query, J. A. (2015), "The Impact of Transportation Costs and Trade Barriers on International Trade Flows", Dissertation, Department of Economics, Graduate School of the University of Oregon, available at: https://scholarsbank.uoregon.edu

8. Victoria Transport Policy Institute (2020), "Transportation Cost and Benefit Analysis II - Literature Review", availalble at: www.vtpi.org/tca/tca02.pdf (last accessed: 19.02.2021).

9. Keya, K. T., Rahman, M. M., Rob, U., Bellows, B. (2014), "Distance, Transportation Cost and Mode of Transport in the Utilization of Facility - Based Maternity Service: Evidence for Rural Bangladesh", International Quarterly of Community Health Education. DOI: https://10.2190/IQ.35.1.d

10. Bernatz, G. (2009),"Apples, Bananas, Oranges: Using GIS to Determine Distance Travelled, Energy Use, and Emissions from Imported Fruit", Papers in Resource Analysis, Saint Mary's University of Minnesota Central Service Press. Winona, MN, Vol. 11, P. 16, available: http://www.gis.smumn.edu (last accessed: 13.02.2021).

11. Chandra, A., Naro, A. (2020), "A Comparative Study of Capacitated Vehicle Routing Problem Heuristics Model", International Journal of Engineering and Emerging Technology, Vol. 5, No. 2, P. 94-100. DOI: https://doi.org/10.24843/IJEET.2020.v05.i02.p015

12. Talbi, E. G. (2009), Metaheuristics: From Design to Implementation, John Wiley and Sons, New Jersey.

13. Vatutin, E. (2017), "Comparisons of Decisions Quality of Heuristics Methods with Limited Depth First Search Techniques in the Graph Shortest Path Problem", De Gruyter Open, P. 428-434. DOI: https://doi.org/10.1515/eng-2017-0041

14. Black, A. P. (2019), "Lecture 6: Exhaustive Serach Algorithms. Department of Compuer Science", Portland State University, available at : https://web.cecs.pdx.edu

15. Droste, I. (2017), "Algorithms for the Traveling Salesman Problem", Thesis, Universiteit Utrecht. Facuteit Betawetenschappen. Netherland, available at: https://dspace.library.uu.nl

16. Balas, E., Toth, P. (1983), "Branch and Bound Methods fo the Traveling Salesman Problem", Management Science Research Report, Carnegie Mellon University, Pittsburgh, Pennsylvania 15213, No. MSRR 488, available at : https://apps.dtic.mil

17. Karaboga, D., Basturk, B. (2008), "On the Performance of Artificial Bee Colony Algorithm", Applied Soft Computing, No. 8, P. $687-697$. DOI: https://doi.org/10.1016/j.asoc.2007.05.007

18. Teodorovic, D., Selmic, M., Davidovic, T. (2015), "Bee Colony Optimization Part II: The Application Survey", Yugoslav Journal of Operations Research, Vol. 25, No. 2, P. 185-219. DOI: https://doi.org/10.2298/YJOR131029020T

19. Gendreau, M. (2002), An Introduction to Tabu Search, Universite de Montreal, Montreal, Canada. Available at: http://www.ifi.uio.no/infheur/Bakgrunn/Intro_to_TS.Gendreau.htm

20. Eglese, R. W. (1990), "Simulated Annealing: A Tool for Operational Research", European Journal of Operational Research, No. 46, P. 271-281. DOI: https://doi.org/10/1016/0377-2217(90)90001-R

21. De Weck, O. (2010), "Lecture 10: Simulated Annealing: A Basic Introduction", MIT OpenCourseWare, available at : http://ocw.mit.edu

22. Zhu, Y. W. (-), "Brute Force", University of Seattle, available at: http://www.fac-staff.seattleu.edu

23. Morrison, D., Jacobson, S. H., Sauppe, J. J., Sewell, E. C. (2016), "Branch and Bound algorithms: A Survey of Recent Advances in Searching, Branching, and Pruning", Discrete Optimization, No. 19, P. 79-102. DOI: http://dx.doi.org/10.1016/j.disopt.2016.01.005

24. Onder, E., Ozdemir, M., Yildrim, B. F. (2013), "Combinatorial Optimization Using Artificial Bee Colony Algorithm and Particle Swarm Optimization Supported Genetic Algorithm", KAU IIBF Dergisi, No. 4 (6), P. 59-70, available at : https://ssrn.com

25. Kocer, H. E., Akca, M. R. (2014), "An Improved Artificial Bee Colony Algorithm with Local Search for Traveling Salesman Problem", Cybernetics and Systems: An International Journal, Vol. 45, No. 8, P. 635-649. DOI: https://doi.org/10.1080/01969722.2014.970396

26. Boussaid, I., Lepagnot, J., Siarry, P. (2013), "A Survey On Optimization Metaheuristics", Information Sciences, No. 237, P. 82-117. DOI: https://doi.org/10.1016/j.ins.2013.02.041

27. Misevicius, A. (2004), "Using Iterated Tabu Search for the Traveling Salesman Problem", Informacines Technologijos Ir Valdymas, No. 3 (32), P. 29-40, available at : https://itc.ktu.lt

28. Zhou, A. H., Zhu, L. P., Hu, B., Deng, S., Song, Y., Qiu, H., Pan, S. (2019), "Traveling-Salesman-Problem Based on Simulated Annealing and Gene-Expression Programming", Information, Vol. 10, No. 7. DOI: https://doi.org/10.3390/info10010007

29. Mataija, M., Segic, M. R., Jozic, F. (2016), "Solving the Traveling Salesman Problem Using the Branch and Bound Method", Zbomik Veleucilista u Rjeci, Vol. 4 No. 1, P. 259-270, available at : https://hrcak.srce.hr 
Вiдомості про авторів / Сведения об авторах / About the Authors

Chandra Agung - Master of Engineering (Civil Engineering), Master of Management (Financial Management), Senior Lecturer, Universitas Mercu Buana, Department of Industrial Engineering, Jakarta, Indonesia; email: agung.chandra@mercubuana.ac.id; ORCID: https://orcid.org/0000-0002-0338-1588.

Агунг Чандра - магістр технічних наук (цивільне будівництво), магістр управління (фінансовий менеджмент), старший викладач університету Мерку Буана, департамент промислового машинобудування, Джакарта, Індонезія.

Natalia Christine - Master of Engineering (Industrial Engineering and Management), Senior Lecturer, Universitas Katolik Indonesia Atma Jaya Jakarta, Department of Industrial Engineering, Jakarta, Indonesia; email: chrisnatalia@atmajaya.ac.id; ORCID: https://orcid.org/0000-0002-4260-684X.

Крістін Наталія - магістр технічних наук (промислова інженерія та управління), старший викладач, католицький університет Індонезії Атма Джая Джакарта, департамент промислового машинобудування, Джакарта, Індонезія.

\section{АНАЛІЗ ЕФЕКТИВНОСТІ МЕТОДІВ ОПТИМІЗАЦІЇ ДЛЯ ВИРІШЕННЯ ПРОБЛЕМИ ПРОДАВЦЯ, ЩО ПОДОРОЖУС}

Предметом цього дослідження є відстань та час декількох проблем з екскурсіями містом, які відомі як проблема продавцямандрівника (ппм). Мета полягає в тому, щоб з'ясувати розриви між відстанями та часом між двома типами методів оптимізації у проблемі продавця, що подорожує: точним та приблизним. Точний метод дає оптимальне рішення, але вимагає більше часу, коли кількість міст збільшується, а приблизний метод дає майже оптимальне рішення, навіть оптимальне, але потребує менше часу, ніж точні методи. Завданням цього дослідження $є$ визначити та сформулювати кожен алгоритм для кожного методу, потім запустити кожен алгоритм з однаковим входом і отримати результат дослідження: загальна відстань, яка надасть можливість порівняти обидва методи: їх перевагу та обмеження. Використані методи - алгоритми Brute Force (BF) та Branch and Bound (B\&B), які класифікуються як точні методи, порівнюються з алгоритмами Artificial Bee Colony $(\mathrm{ABC})$, Tabu Search (TS) та Simulated Annealing (SA), які класифікуються як приблизні методи, або відомі як методи евристики. Ці три наближені методи обрані, оскільки вони є ефективними алгоритмами, прості у реалізації та забезпечують хороші рішення для комбінаторних задач оптимізації. Точні та приблизні алгоритми перевіряються у кількох розмірах задач екскурсії містом: 6, 9, 10, 16, 17, 25, 42 та 58 міст. 17, 42 та 58 міст вибрані з ппмlib: бібліотеки зразків екземплярів для ппм; а інші взяті з великих міст острова Ява (Західний, Центральний, Східний). Всі алгоритми запущені програмою MATLAB Результати показують, що точний метод кращий у часі за обсягом завдання на менше ніж 25 міст, коли і точні, i приблизні методи дають оптимальне рішення. Для обсягів завдання, яке враховує більше 25 міст, приблизний метод - Artificial Bee Colony (ABC) дає кращий час, який приблизно на 37\% менше, ніж точний, і відхиляється на 0,0197\% для відстані від точного методу. Висновок полягає у застосуванні точного методу для обсягу проблеми менше 25 міст та приблизного методу для обсягу проблеми більше 25 міст. Розрив у часі буде збільшуватися між двома методами, коли обсяг вибірки стає більшим.

Ключові слова: проблема продавця, що подорожує; метод оптимізації; точний метод; наближені методи; прогалини.

\section{АНАЛИЗ ЭФФЕКТИВНОСТИ МЕТОДОВ ОПТИМИЗАЦИИ ДЛЯ РЕШЕНИЯ ПРОБЛЕМЫ ПРОДАВЦА, КОТОРЫЙ ПУТЕШЕСТВУЕТ}

Предметом настоящего исследования является расстояние и время нескольких проблем с экскурсиями по городу, которые известны как проблема продавца-путешественника (ппп). Цель состоит в том, чтобы выяснить разрывы между расстояниями и временем между двумя типами методов оптимизации в проблеме продавца, который путешествует: точным и приблизительным. Точный метод дает оптимальное решение, но требует больше времени, когда количество городов увеличивается, а примерный метод дает почти оптимальное решение, даже оптимальное, но требует меньше времени, чем точные методы. Задачей данного исследования является определить и сформулировать каждый алгоритм для каждого метода, затем запустить каждый алгоритм с одинаковым входом и получить результат исследования: общее расстояние, которое даст возможность сравнить оба метода: их преимущество и ограничения. Использованные методы - методы Brute Force (BF) и Branch and Bound (B \& B), которые классифицируются как точные методы, сравниваются с алгоритмами Artificial Bee Colony (ABC), Tabu Search (TS) и Simulated Annealing (SA), которые классифицируются как приблизительные методы или известны как методы эвристики. Эти три приближенные методы выбраны, поскольку они являются эффективными алгоритмами, просты в реализации и обеспечивают хорошие решения для комбинаторных задач оптимизации. Точные и приблизительные алгоритмы проверяются в нескольких размерах задач экскурсии по городу: 6,9 , $10,16,17,25,42$ и 58 городов. 17, 42 и 58 городов выбраны из пппlib: библиотеки образцов экземпляров для ппп; а другие взяты из крупных городов острова Ява (Западный, Центральный, Восточный). Все алгоритмы запущены программой MATLAB. Результаты показывают, что точный метод лучше во времени по объему задания на менее чем 25 городов, когда и точные, и приблизительные методы дают оптимальное решение. Для объемов задачи, которая учитывает более 25 городов, приблизительный метод - Artificial Bee Colony (ABC) дает лучшее время, которое примерно на 37\% меньше, чем при точном методе, и отклоняется на $0,0197 \%$ для расстояния точного метода. Вывод заключается в применении точного метода для объема проблемы менее 25 городов и приблизительного метода для объема проблемы более 25 городов. Разрыв во времени будет увеличиваться между двумя методами, когда объем выборки становится больше.

Ключевые слова: проблема продавца, который путешествует; метод оптимизации; точный метод, приближенные методы; разрывы.

Бібліографічні описи / Bibliographic descriptions

Chandra Agung, Natalia Christine (2021), "Performance analysis of optimization methods for solving traveling salesman problem", Innovative Technologies and Scientific Solutions for Industries, No. 1(15), P. 69-75. DOI: https://doi.org/10.30837/ITSSI.2021.15.069 